\title{
Government Briefing: Incorporating Free, Prior and Informed Consent into Investment Approval Processes
}

July 2020

Kelly Dudine and Sam Szoke-Burke

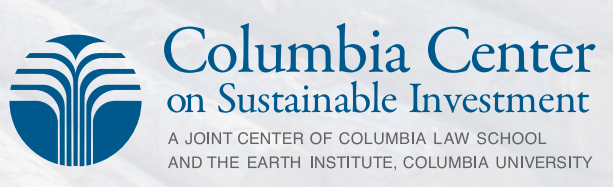

\section{Why consent matters}

Governments are legally bound by international law to respect and fulfill human rights, and to protect individuals and groups from rights violations by businesses, among other actors. In addition to causing disastrous outcomes for rights holders, these violations also have negative effects for businesses, including business-community conflict, which can destroy the viability and profitability of investment projects.

Enabling meaningful participation by rights holders and obtaining and maintaining their Free, Prior and Informed Consent (FPIC) helps governments to mitigate such risks, fulfil their legal obligations, and, ultimately, attract better investments.

This briefing explains how host government agencies involved in investment processes can effectively apply FPIC to:

1. Facilitate the right kind of investments, which operate responsibly and support sustainable development

2. Increase business confidence by fostering a stable and participatory investment environment

3. Comply with international law and align approval processes with industry standards and best practices

4. Avoid and mitigate financial, political, and legall risks

5. Manage potential conflicts that risk violating human rights and damaging business operations and the national interest.

\section{Who is this briefing for?}

This briefing is for host government entities who promote, screen, approve, and monitor land-based investments, including agricultural, forestry, or renewable energy projects. It may be relevant for investment promotion agencies, ministries of land, agriculture, forestry, energy, renewable energy, finance, economy, and/or rural development, environmental protection agencies, and local government entities, among others.

\section{What is Free, Prior and Informed Consent?}

Free, Prior and Informed Consent (FPIC) refers to the right of a community or people to participate in decisionmaking on issues relevant to their well-being, and to give or withhold consent to any project or policy that would affect them or their lands or resources. While traditionally attributed to Indigenous and tribal peoples under international law, various industry and multi-stakeholder initiative standards require businesses to obtain the FPIC of all project-affected communities (see Box 2).

The components of FPIC include:

1. Free: Community members give or withhold consent voluntarily, without coercion, intimidation or manipulation.

2. Prior: Consent is obtained well before each stage of project authorization, and is actively sought and maintained on an ongoing basis throughout the life of a project.

3. Informed: Community members access, understand, and deliberate on all relevant project information before giving or withholding consent.

4. Consent: Community decisions to agree to, refuse, or offer conditional consent to projects or activities that affect their land or resources are respected. 
"Communities need to be involved from the very beginning to the very end. Obtaining FPIC is a continual process."

\author{
- Francis W Mwah \\ Assistant Director and Senior Economist, \\ Ministry Of Agriculture, Liberia
}

\section{Box 1: Interpreting FPIC obligations in Kenya and the Philippines}

In 2010, the African Commission on Human and Peoples' Rights ruled in favor of the Indigenous Endorois people, stating their eviction from ancestral lands by the government of Kenya was illegal. ${ }^{1}$ In a similar decision, the African Court of Human and Peoples' Rights ruled in favor of the Indigenous Ogiek people against the government of Kenya in 2017. ${ }^{2}$ In each case, the Commission and the Court noted the rights of Indigenous people in Africa to determine how their lands and resources are used.

In 1994, TVI Resources Development Inc, a mining company, began operations in Mindanao, Philippines, ${ }^{3}$ within the ancestral domain of the Indigenous Subanon people. The Philippine government, a major investor in the project, largely ignored community complaints that the company had not obtained the community's FPIC. In 2007, the UN Committee for the Elimination of Racial Discrimination issued a recommendation that the government consult with all affected parties in a manner respecting the rights of the Subanon people. Due to mounting pressure, the government ultimately acknowledged its failure to obtain FPIC, and in 2011, TVI publicly admitted wrongdoing and agreed to pay fines and penalties.

\section{Box 2: Industry standards that require FPIC}

While initially emerging as a right of Indigenous and tribal peoples, FPIC is increasingly required by various industry and multi-stakeholder initiative standards to be obtained from all affected communities. These include the principles and criteria of the Forest Stewardship Council and the Roundtable on Sustainable Palm Oil, and the EO100 Standard for Responsible Energy. Investment managers also increasingly screen potential investments for environmental, social and governance (ESG) risks, meaning that projects with human rights abuse allegations or risks, including due to a failure to obtain FPIC, may find it increasingly difficult to secure capital.

\section{Involving all community members}

Meaningful participation and FPIC requires more than engagement with local officials and community leaders. All members of a project-affected community must be able to participate and make an informed decision, including women, young people, the elderly, ethnic minorities, people with disabilities, and other groups. Less visible groups who may need to be involved include seasonal users of land within or near the project boundaries, and people who reside elsewhere but still have historical claims or cultural ties to the land or resources in question.

\footnotetext{
1 African Commission on Human and Peoples' Rights, 276/03 Centre for Minority Rights Development (Kenya) and Minority Rights Group (on behalf of Endorois Welfare Council) v. Kenya (Nov. 25, 2009): http://tiny.cc/ACHPRDecision.

2 African Court on Human and Peoples' Rights, African Commission On Human And Peoples' Rights v. Republic of Kenya, Application No. 006/2012, Judgment (May 26, 2017): https://cutt.ly/8uN6sYC.

3 UN Committee on the Elimination of Racial Discrimination, Correspondence to the Government of Philippines (Aug. 27, 2010): http://tiny.cc/OHCHRletter.
} 


\section{Basic FPIC characteristics}

To align investment approval processes with FPIC standards:

- Establish a formal process to conduct community consultations with the objective of obtaining FPIC. Make the process adaptable to the local customs of each community.

- Engage all communities likely to be affected.

- Make sure consultations target all members and groups within each community and not just community leaders and elites.

- Enable community access to relevant information needed to make an informed decision. This may include visits to comparable sites, dialogues with communities or social movements who have experienced similar projects, and reliable information about expected revenues, job creation and benefit sharing flows to the community.

- Conduct consultations, and provide materials, in local language(s) and in accessible and not too detailed or technical formats so that community members can easily understand the information.

- Facilitate community access to independent experts and support so they can participate in an organized and confident manner. Consider establishing and/or requiring businesses to pay into an independent basket fund for community support. ${ }^{4}$

- Give the community sufficient time to appraise itself of the situation, organize internally and come to an informed and unified decision according to its traditional decision-making processes.

- Require all parties to respect the community's decision to give or withhold its consent to a project.

- Do not pressure community members to meet during events that make it unsafe to gather publicly or internally, such as health or security crises. Halt decision-making processes until community participation can safely resume.

\section{Box 3: Women's participation}

Women may often be less likely to participate in consultative processes due to local gender norms, household responsibilities, or social hierarchies. Bolster women's participation by identifying local gender champions to support the design of gender-sensitive consultation and FPIC processes. This may include having women-only meetings, which are led or co-led by women, to encourage their participation, as well as calibrating outreach and educational efforts to actually reach women at the locations and the times that suit them best.

\section{Box 4: FPIC helps governments manage risk}

Governments will face criticism for abuses committed by businesses, as well as failures to adequately include communities in decision-making. Embedding an FPIC requirement into investment approval processes can help governments avoid:

- Legal risks associated with violating national or international laws or standards which can bring accompanying penalties, costs and pressure from the international community.

- Reputational risks, such as criticism from other governments, civil society, and citizens, which can deter potential business partners, harm relations with development partners, and weaken the government's bargaining position in future contract negotiations.

- Economic risks caused by the failure, abandonment or poor performance of investments and reduced projected fiscal revenue, job-creation and infrastructure construction. Such outcomes undermine domestic economic development strategies.

- Political risks, including a loss of political support at home, which can threaten the government's perceived legitimacy.

- Social risks that sow the seeds of distrust within local communities and can increase the risk of human rights violations and governmentcommunity conflict. 


\section{Stage 1: Creating an Enabling Environment and Attracting the Right Investors}

Governments can achieve an enabling environment for responsible investment by designing and implementing legal and policy frameworks, approaches, and strategies that encourage and facilitate the most responsible projects and practices.

FPIC and meaningful community participation in decisionmaking are crucial elements for an enabling environment. An investment context that takes FPIC and participation seriously can help governments to encourage respect for community rights, set clear expectations for positive business-community relations, prevent future conflicts, and achieve national development goals.

In some cases, governments may aim to incentivize certain investments and/or streamline investment processes by creating special economic zones, development zones, or priority areas. In such cases, the need for FPIC and meaningful community consultation will be as crucial as ever.

\section{How to incorporate FPIC in the development of} legal and policy frameworks:

- Promote the benefits of FPIC to all levels of government actors, both within and outside of your agency, to help establish buy-in needed to secure financial and human resources for FPIC implementation. Use the text box examples in this briefing.

- Establish rules for how your agency will engage with communities to design a FPIC process that is contextually appropriate.

- Establish FPIC processes for the development of laws, policies, regulations, treaties and other instruments that affect the rights of Indigenous and other communities (see Box 5, below). In addition, facilitate participation and input from other citizens, civil society organizations, government bodies, religious leaders, and other actors who may be affected by, or have important insights for, the instrument being developed.

- Make sure FPIC requirements apply both to the government, when it acquires land to lease to businesses, and to businesses, when they directly acquire rights to use land.
- Design assessment criteria that evaluate proposed projects' likely impacts on human rights, the environment, and sustainable development. Develop robust due diligence processes to assess each business's capacity, reputation and past performance.

- Empower communities to develop their own FPIC protocols, which explain how external actors should interact with them and seek their FPIC. Publicly commit to, and require businesses to, follow such protocols.

- Legally recognize all legitimate tenure rights, including those not formally documented, and provide legal education for all community members about their rights.

\section{Box 5: FPIC and consultation during the development of laws and policies}

International law requires governments to consult with Indigenous and tribal peoples for the development of laws and administrative measures that affect them. The International Labour Organization's Indigenous and Tribal Peoples Convention, known as ILO C169, requires governments to consult the peoples concerned on any legislative or administrative measures which may affect them directly. ${ }^{5}$ The United Nations Declaration on the Rights of Indigenous Peoples (UNDRIP), a soft law document regarded to contain many binding customary legal principles, takes this a step further, requiring governments to consult with Indigenous peoples in order to obtain their FPIC before implementing any legislative or administrative measure that may affect them. ${ }^{6}$

In 2011, the government of Peru passed Law 29785 which seeks to implement ILO C169's requirement to consult Indigenous people on relevant administrative or legal measures. While the law does not require that FPIC is obtained, it does show that national consultations with Indigenous peoples on laws and policies can be operationalized. In light of Law 29785, Peru's government began a formal consultation process with Indigenous and other organizations to develop the country's Legal Framework for Climate Change in 2019. 


\section{Box 6: Incorporating FPIC requirements within domestic laws and policies}

Liberia recently passed the Land Rights Act of 2018, which recognizes and protects the customary land rights of millions of Liberians. The government collaborated with civil society organizations and other local partners to develop the Act, which includes a requirement to obtain any community's FPIC for future "interferences" with customary land.

In 2017, the government of Sierra Leone began to align its agribusiness investment approval process with the Voluntary Guidelines on Responsible Governance of Tenure of Land, Fisheries and Forest Resources, a softlaw document developed through a multi-stakeholder process convened by the Committee on World Food Security. The resulting policy calls on businesses to consult project-affected communities and to deepen community engagement while conducting feasibility studies and environmental and social impact assessments. A recently updated version of this policy, currently in draft form, requires that community members provide their FPIC to all contracts authorizing agricultural projects, including contracts to which community members are not parties. Sierra Leone's Model Customary Land Rights Bill 2020 also states that "no investment of any kind shall take place on any land in the provinces" without the FPIC of holders of customary or other land rights.

\section{Stage 2: Registration of Intent and Screening}

Once a business registers its intention to invest in a country, the government usually screens both the business and its proposal for appropriateness and feasibility. At this stage, the government can apply the screening criteria established in Stage 1 to decide to reject or suggest adjustments to potentially harmful projects or whether a proposal is promising enough to be worthy of further consideration.

\section{How to incorporate FPIC principles into screening and due diligence:}

- Use the criteria established in Stage 1, above, to screen proposed projects. Reject those that do not align with the country's development strategy and that pose significant risks of human rights violations.

- Conduct due diligence on the business, its parent company and its subsidiaries, where applicable. Review its past projects and behavior, including regarding profitability and human rights impacts. Request and analyze information on the business's human rights and community engagement policies and processes to determine whether it is well placed to respect rights and FPIC requirements, local customs, and national laws.

- Make information about the business and the project available to the public, including in areas where the project might occur, so that grass-roots and civil society organizations can provide feedback and comments on the business and the proposal. 


\section{Stage 3: Community Consultation and Impact Assessments}

Projects that progress beyond the initial screening are then subjected to more in-depth evaluations to determine social, environmental and economic viability. International norms, multilateral resolutions, and the authoritative interpretations of some UN treaty bodies call on governments to consult Indigenous and other communities regarding proposed projects on, or that may affect, their lands and resources. ${ }^{7}$ Additionally, multilateral and industry standards require governments and businesses to conduct human rights due diligence and/or impact assessments to identify and address a project's potential environmental, social, and/or human rights impacts. ${ }^{8}$ In practice, governments may take on these responsibilities or they may require businesses to conduct assessments, which the government then reviews for approval.

Legal expert Dr Cathal Doyle notes that for a human rights impact assessment (HRIA) to be FPIC-compliant, the community "would decide whether HRIAs are to be conducted (consent) and control the conditions under which they are conducted (free), as well as their timing, sequencing and frequency (prior), and how and what information is produced and assessed as part of them (informed)." 9 An FPIC-compliant impact assessment can also help avoid counterproductive or ineffective assessments, as community members are often well placed to reveal hidden risks before they become sources of tension or conflict, or cause costly delays.

\footnotetext{
7 See, e.g., UN Committee on Economic, Social and Cultural Rights (CESCR). Concluding Observations of the Committee on Economic, Social and Cultural Rights - Mexico, UN Doc. E/C.12/MEX/CO/4 (June 9, 2006), Sections D and E, para 1: http://tiny.cc/CESCRmexico; Office of the U.N. High Commissioner for Human Rights, Report on Factors that Impede Equal Political Participation and Steps to Overcome Those Challenges, U.N. Doc. A/HRC/27/29 (June 30, 2014), para. 89: https://tinyurl.com/y7lpduo8; African Union, African Convention On The Conservation Of Nature And Natural Resources (Revised) (March 07, 2017), Art. XVII(3): http://tiny.cc/AUNaturalReso.

8 See African Commission on Human and Peoples' Rights, 224 Resolution on a Human Rights-Based Approach to Natural Resources Governance, Doc. ACHPR/ Res.224(LI)2012, paras. ii and 4: http://tiny.cc/224Resolution and United Nations, Guiding Principles on Business and Human Rights: Implementing the United Nations "Protect, Respect and Remedy" Framework UN Doc. HR/PUB/11/04 (2011), http://tiny.cc/UNGPs. See also Box 2, above.

9 Cathal Doyle, "Indigenous Peoples' Rights: Is HRIA an Enabler for Free, Prior and Informed Consent?," in Nora Götzmann (ed.), Handbook on Human Rights Impact Assessment (2019), p. 136
}

\section{How to effectively incorporate FPIC into consultations and impact assessments:}

- For consultation processes, follow the Basic FPIC Characteristics, above, page 3. Remember: not all community consultations are adequate to ensure FPIC is obtained and maintained.

- Hold, or require businesses to hold, ongoing information sessions and two-way dialogues about the project with all potentially affected community members. Make sure that the community has: access to independent experts and support; and sufficient time to understand their rights and the project's likely impacts, deliberate internally, and decide whether or not they wish for an impact assessment to take place-and, if so, when.

- Empower the community to choose trusted and capable representatives, including representatives of groups within the community, such as women and ethnic minorities.

- Work collaboratively with experts, local organizations, and community representatives to collaboratively design and, potentially, conduct impact assessments and develop management plans for all risks identified. ${ }^{10}$

- Respect any community decision to give conditional consent, or withhold consent once the impact assessment is completed. Where the community decides not to consent, cease project planning or, if the community has indicated an openness to future proposals, revise the project proposal in line with community feedback and concerns, and then repeat this stage.

- Prepare FPIC guidance for businesses who will have to obtain community consent. ${ }^{11}$ Where businesses claim to have obtained FPIC, check with different community groups. Require the business to provide reports from all consultations, including information on attendees, materials provided, and meeting minutes and outcomes. This should include evidence of how community feedback was subsequently factored into project decision-making, what support the community received and who paid for it, and how the community provided its FPIC.
10 See Columbia Center on Sustainable Investment, Danish Institute for Human Rights and Sciences Po Law School Clinic, A Collaborative Approach to Human Rights Impact Assessments (2017): http://tiny.cc/HRIAs.

11 For examples of company guidance on FPIC and consultation see the Responsible Land-Based Investments Navigator, https://bit.ly/2NNaRww 


\section{Box 7: The legal risks of ignoring FPIC}

In 2015, wind energy company Energía Eólica del Sur obtained permits to construct a wind farm in Oaxaca, Mexico, worth US $\$ 730$ million, but its poor engagement with the local Indigenous Zapotec community caused disruptive conflict. ${ }^{12}$ Following community complaints that earlier consultations had failed to obtain their FPIC to use the land, a state court halted operations and the principal investor rescinded its financial commitment, citing the controversy surrounding the project. The case eventually went before Mexico's Supreme Court, which ruled against the company for violating the community's consultation rights.

\section{Stage 4: Permits, Contract Negotiation, and Approval}

If impact assessments are approved and all projectaffected communities have provided preliminary consent to the project, permits and licences must be obtained in accordance with national laws and regulations. Businesses will usually also negotiate a contract, such as a concession contract or a lease, with the government or the local community.

FPIC at this stage helps to establish working arrangements with the community to avoid violation of community rights, manage each stakeholder's expectations, build consensus, and prevent delays in project development. Communitybusiness contracts can also be used to secure community entitlements to financial transfers, job creation and other "benefits" from the project. ${ }^{13}$
For contract negotiations between the business and the government, FPIC can be incorporated in different ways, including:

1. Involve the community in negotiations and as a party to the contract. This makes the contract a multi-actor or "tripartite" investment contract. ${ }^{14}$ This is the most efficient and concrete FPIC mechanism in investment contract negotiations, as the community can influence the contract's content, obtain rights to enforce the contract if breached, and, if it wishes, use the contract to provide its formal consent to the project.

2. Invite the community to attend and actively participate in negotiations. This option increases the community's access to information and ability to influence negotiations, although the community's ability to give or withhold its FPIC may be limited as it is not a contractual party. A community willing to consent to the project could formally do so in a separate process and/or contract with the business or government.

3. Conduct periodic community consultations during negotiations. Negotiate the contract in rounds, and hold broad and inclusive community consultations between each round to report back to, and gain input from, the community. See Basic FPIC Characteristics, above. While this option affords the community some say in contract negotiations, absence from the negotiating table limits the community's ability to access information, provide timely feedback, influence the terms of the project, and insist on any decisions to withhold its FPIC. The rounds of negotiations would also likely take more time than if the community were present during negotiations. As for the previous option, a consenting community could provide its FPIC in a separate process and/or contract with the business or government.

For negotiations between the business and the community, FPIC can be incorporated by incorporating the following steps. 
How to incorporate FPIC into business-state or community-business negotiations:

- Facilitate community access to interpreters, independent technical and legal empowerment support. Consider establishing and/or requiring businesses to pay into an independent basket fund to finance this support.

- Allow community representatives sufficient time to report back to the community to gain input as needed, including time for community members to review information, access resources, discuss their views, and articulate their position.

- State in the contract that the community has enforceable rights to hold the government and the business to account if they breach the contract. Where the community is not a contractual party, this can be done by inserting a "third party beneficiary" clause.

- Decide with the community how often FPIC should be renewed (for example, every 1 or 3 years) and include this in the contract, while noting the right of communities to withdraw consent at any time.

- Incentivize the business to comply with all contracts. If the business negotiates separate contracts with the government and the community, consider a clause that deems a business's breach of a community contract to be taken as a breach of its government contract, which could imperil its investment authorization.

- Community participants in negotiations may spend a lot of unpaid time. Consider how to compensate them without creating undue influence, perverse incentives or conflicts of interest. To facilitate women's participation, hold negotiations at times that suit them and, where relevant, provide childcare support.

\section{Stage 5: Throughout the Life of the Project}

FPIC is an ongoing right that requires the community to be involved in decision-making processes throughout a project's lifespan. Incorporating FPIC throughout the life of the project helps businesses and communities adapt to unforeseen challenges-including negative project impacts and changes in the local context, market conditions, or business approaches-and understand and respond to each others' needs on an ongoing basis.

\section{How to incorporate FPIC throughout the life of the project}

- Establish regular business-community consultations and dialogue to keep the community informed on any developments, such as changes to project plans.

- Consider establishing a multi-stakeholder dialogue for community members, civil society, the business, and government representatives to regularly communicate and collaborate. Manage power imbalances, including by facilitating support and resources for communities, establishing strong objectives and governance arrangements, and appointing a trusted and impartial facilitator.

- Require businesses to regularly report to the government and community on project implementation and any benefit-sharing commitments. Require data to be shared in an accessible format and timely manner.

- Monitor business compliance with its obligations to the government and community, and regularly assess the project's impact on communities and the environment.

- Facilitate community monitoring of project impacts and business compliance, including by allowing the community to access to the project site and information, and arranging for an independent basket fund to finance technical support for community monitors as needed.

- Align government monitoring and business reporting activities with local customs, in consultation with the community where necessary.

- Establish an accessible and effective grievance mechanism, consistent with the UN Guiding Principles on Business and Human Rights, to resolve disputes or community grievances about the project or any FPIC process.

Learn More at ccsi.columbia.edu or contact us at ccsi@ law.columbia.edu 


\section{Acknowledgements:}

We are extremely grateful to Jesse Coleman, Tehtena Mebratu-Tsegaye, Carole Muriuki, and Darryl Vhugen for their probing peer reviews and to Victor Bangura and Francis Mwah for additional assistance.

Design by Michael J Morgan

Cover Photo by Fabian Plock on Shutterstock Page 9 Photo by Daniel Machacek on Shutterstock

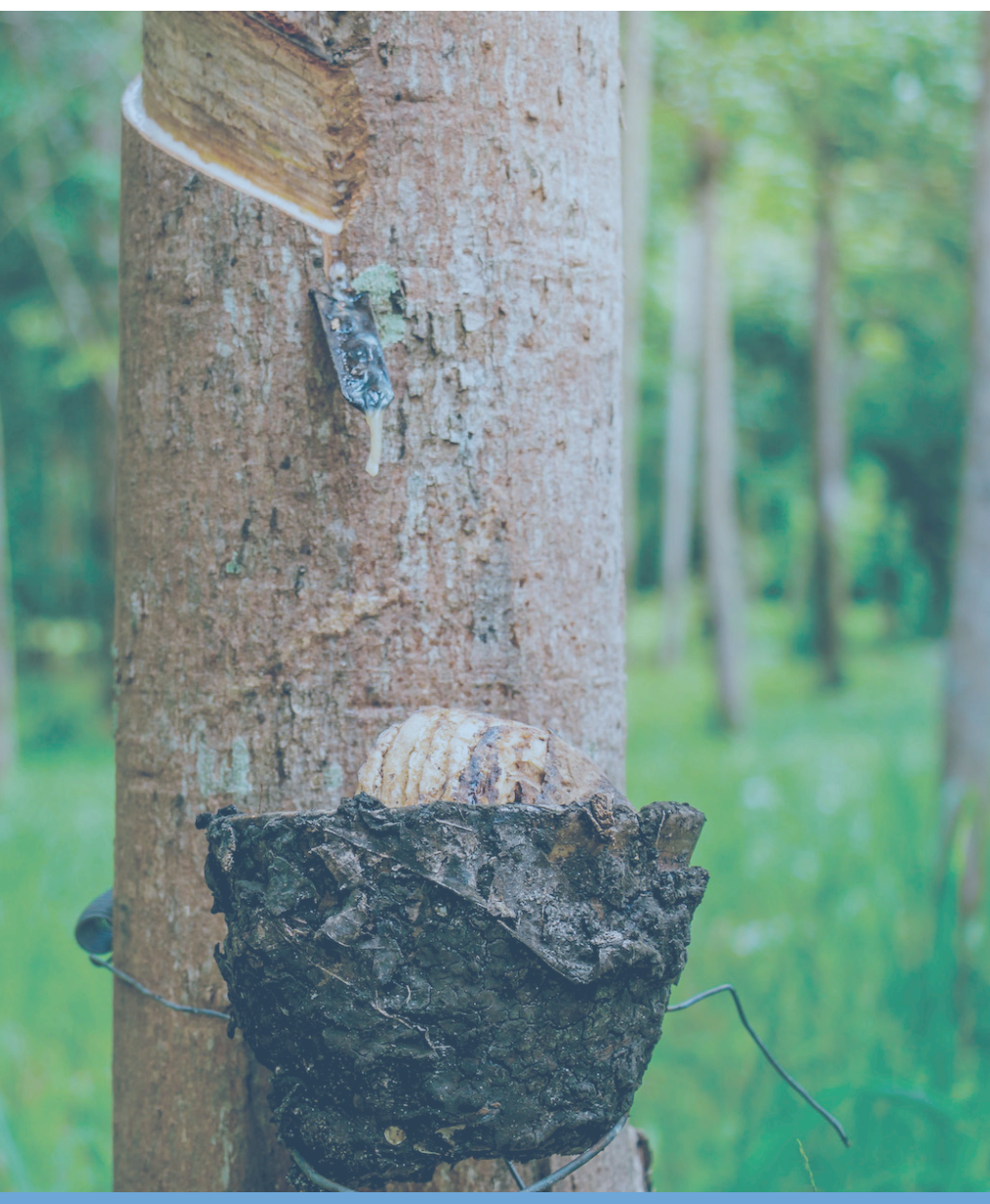

ccsi.columbia.edu

Columbia Center on Sustainable Investment

Jerome Greene Hall 435 West 116th Street

New York, NY 10027

Phone: +1 (212) 854-1830

Email: ccsi@law.columbia.edu 